\title{
INFLUENCE OF FLUVOXAMINE ON CARVEDILOL'S PHARMACOKINETICS IN RATS
}

\author{
MARIA BIANCA ABRUDAN ${ }^{1}$, DANA MARIA MUNTEAN ${ }^{1}{ }^{*}$, LAURIAN VLASE $^{1}$, ANA-MARIA \\ GHELDIU $^{1}$, CRISTIAN BERCE ${ }^{2}$, LAURENTiIU STOICESCU ${ }^{3}$, MARIA ADRIANA NEAG ${ }^{4}$ \\ ${ }^{I}$ Department of Pharmaceutical Technology and Biopharmaceutics, Faculty of Pharmacy, "Iuliu Hațieganu” University of \\ Medicine and Pharmacy, 41 Victor Babeș, Cluj-Napoca 400012, Romania \\ ${ }^{2}$ Centre for Experimental Medicine, "Iuliu Hațieganu” University of Medicine and Pharmacy, 6 Louis Pasteur, Cluj-Napoca \\ 400349, Romania \\ ${ }^{3}$ Department of Cardiology, Vth Medical Clinic, Clinical Municipal Hospital, "Iuliu Hațieganu” University of Medicine and \\ Pharmacy, Faculty of Medicine, 11 Tăbăcarilor, Cluj-Napoca 400139, Romania \\ ${ }^{4}$ Department of Pharmacology, Toxicology and Clinical Pharmacology, Faculty of Medicine, "Iuliu Hațieganu” University \\ of Medicine and Pharmacy, 41 Victor Babeș, Cluj-Napoca 400012, Romania
}

*corresponding author:dana.muntean@umfcluj.ro

\begin{abstract}
Carvedilol is one of the most used cardiovascular drugs, highly metabolized by CYP450 2D6, 1A2, 2C9. Fluvoxamine, an antidepressant agent, is a moderate/potent inhibitor of these enzymes. There is the risk of drug-drug interaction when these two drugs are concomitantly administered. The aim of this study was to investigate the drug-drug interactions between carvedilol and fluvoxamine in rats. There were two periods: reference and test. In the first period each rat received an oral dose of $3.57 \mathrm{mg} / \mathrm{kg}$ body weight carvedilol. In the test period, carvedilol was administered after a pre-treatment with multiple oral doses of fluvoxamine $(14.28 \mathrm{mg} / \mathrm{kg}$ b.w.). HPLC-MS was used to determine the plasma concentration of carvedilol. The PK parameters were calculated by non-compartmental analysis. Fluvoxamine co-administered with carvedilol can change the PK parameters (increase $\mathrm{AUC}, \mathrm{t}_{1 / 2}$, decrease the $\mathrm{Cl}$ ). The present study demonstrated the pharmacokinetic drug-drug interaction between carvedilol and fluvoxamine in vivo.
\end{abstract}

\section{Rezumat}

Carvedilolul este unul dintre cele mai utilizate medicamente cardiovasculare, intens metabolizat prin intermediul CYP450 2D6, 1A2, 2C9. Fluvoxamina, agent antidepresiv, este un inhibitor moderat/puternic al acestor enzime. La co-administrarea acestor două medicamente, există riscul apariției unei interacțiuni. Scopul studiului este de a investiga interacțiunea dintre carvedilol și fluvoxamină, la șobolani. Există două perioade: referință și test. În prima perioadă, fiecare şobolan a primit o doză de $3,57 \mathrm{mg} / \mathrm{kg}$ carvedilol. În perioada test, carvedilolul a fost administrat după un pre-tratament cu doze orale multiple de fluvoxamină $(14.28 \mathrm{mg} / \mathrm{kg})$. Pentru determinarea concentrațiilor plasmatice de carvedilol, s-a folosit sistemul HPLC-MS. Parametrii farmacocinetici s-au calculat prin analiza non-compartimentală. Co-administrarea fluvoxaminei cu carvedilolul a dus la modificarea parametrilor farmacocinetici (creșterea AUC, a $\mathrm{t}_{1 / 2}$, scăderea $\mathrm{Cl}$ ). Studiul a demonstrat existența interacțiunii in vivo între carvedilol și fluvoxamină.

Keywords: Carvedilol, cytochrome P450, inhibition

\section{Introduction}

Carvedilol is a non-selective beta-blocker drug with additional blockades of $\alpha_{1}$ receptors [3, 29]. Nowadays, this drug is mostly used in cardiology having many beneficial effects: decreases the blood pressure, induces vasodilation, antioxidant and antiproliferative effects [21, 27, 31]. Due to these effects carvedilol is indicated in patients with hypertension, ischemic heart disease or chronic heart failure [15]. The clinically used carvedilol is a mixture between $\mathrm{S}$ and R-carvedilol. These two enantiomers act differently: R-carvedilol blocks $\alpha_{1}$ adrenergic receptors while S-carvedilol blocks $\alpha_{1}, \beta_{1}$ and $\beta_{2}$ receptors [23, 34].
Carvedilol is well absorbed from gastro-intestinal level, is bound in high proportion to plasma proteins $(98 \%)$ and is metabolized in the liver [22] through both oxidation and glucuronidation reactions. The results of these processes are few metabolites: 4'hydroxyphenyl carvedilol, 5'-hydroxyphenyl carvedilol, O-desmethyl carvedilol, hydroxy carbazolyl [28, 33]. CYP2D6 and CYP1A2 are the main enzymes which catalyse the oxidation of carvedilol in humans [35]. 4' and 5'-hydroxyphenyl carvedilol is formed by action of CYP2D6 enzyme, hydroxy carbazolyl by CYP1A2 and O-desmethyl carvedilol by CYP2C9 [25, 28]. It was demonstrated that the active metabolite 4'-hydroxyphenyl carvedilol has higher beta-blocking effect than carvedilol $[1,7]$. 
FARMACIA, 2019, Vol. 67, 4

Fluvoxamine is an antidepressant agent which belongs to the selective serotonin reuptake inhibitors, SSRIs $[11,14]$ and is used in patients with depression or other psychiatric diseases $[13,20]$. It has a good absorption (more than 90\%) and a low plasma protein binding $(77 \%)$, being metabolized in the liver and excreted in urine $[9,10,16]$. Fluvoxamine is a potent inhibitor of CYP1A2 and CYP2C19 and moderate inhibitor of CYP2C9, CYP2D6 and CYP3A4 [4, 32]. Due to fluvoxamine inhibitory effect on the enzymes which metabolize carvedilol, fluvoxamine may influence carvedilol's pharmacokinetics. So, the aim of this study was to investigate the pharmacokinetic interactions between fluvoxamine and carvedilol when these two drugs are concomitantly administered. There are many patients suffering from cardiovascular and psychiatric diseases who use carvedilol and fluvoxamine as treatment at the same time. The results of this study could have an important role in the pharmacotherapy and safety profile of carvedilol, by choosing the right treatment plan when these drugs are used concomitantly.

\section{Materials and Methods}

Chemicals and reagents

Carvedilol and fluvoxamine were purchased from Moehs (Rubí, Spain). HPLC-grade acetonitrile, 98\% formic acid and methanol of analytical-reagent grade were purchased from Merck KGaA (Darmstadt, Germany). Heparine sodique 25,000 UI/5 mL (5,000 $\mathrm{UI} / \mathrm{mL}$ ) was acquired from Panpharma Laboratoires (France).

In this study, there were used the following apparatus: BASi Culex $\mathrm{ABC}^{\circledR}-$ Automatic Blood Collector (BASi, Indiana, USA); two HPLC systems - Agilent 1100 series (binary pump, autosampler, thermostat; Agilent Technologies $^{\circledR}$, USA) - coupled with a Bruker Ion Trap VL (Bruker Daltonics GmbH ${ }^{\circledR}$, Germany). Animal treatment

Thirteen $(\mathrm{n}=13)$ male $\mathrm{Crl}$ :WI rats with a median weight of $330 \pm 20 \mathrm{~g}$ were used in the present study. The animals were housed in polysulfone type III-H open-top cages (Tecniplast, Buguggiate, Italy) and had access to filtered tap water in bottles and pelleted feed (Cantacuzino Institute, Bucharest, Romania) ad libitum. The bedding was a standard wood chip aseptic bedding (Lignocel ${ }^{\circledR}$; J. Rettenmaier \& Söhne GmBH+ Co. KG, Rosenberg, Germany). The rats were acquired from the Centre for Experimental Medicine of the "Iuliu Hațieganu" University of Medicine and Pharmacy and were kept at a standard temperature of $20 \pm 2{ }^{\circ} \mathrm{C}$ and a relative humidity of $55 \pm 10 \%$, in a $12: 12$ hour light:dark cycle (lights on, 7 am to $7 \mathrm{pm}$ ) with a light intensity of $285 \mathrm{~lx}$ at $1 \mathrm{~m}$ above the floor. All experimental protocols were approved by the Ethics Committee of "Iuliu Haţieganu" University of Medicine and Pharmacy and by the Romanian National Sanitary
Veterinary and Food Safety Authority (authorization number 8/27.10.2016) and were conducted in accordance with "Guide for the care and use of Laboratory Animals" $8^{\text {th }} \mathrm{Ed} / 2011$, and the EU Directive 63/2010. Prior to the onset of the study, all animals were quarantined and left to acclimatize to the separation from the rat colony for 7 days. The "Guiding Principles in the Use of Animals in Toxicology" adopted by the Society of Toxicology (USA) and the Law 43/2014 regarding the protection of animals used for scientific research were the specific regulations and amendments from this study.

The connection of the animal to BASi Culex $\mathrm{ABC}^{\circledR}$ needs the cannulation on the left femoral vein of the rat. Before performing the cannulation procedure, each animal was anesthetized with a combination of anaesthetics: diazepam (Diazepam ${ }^{\circledR}$, Terapia SA, Romania), ketamine (Vetased $^{\circledR} 10 \%$, Farmavet, Romania) and xylazine (XylazinBio ${ }^{\circledR} 2 \%$, Bioveta, Czech Republic) (1:1:1).

High-performance liquid chromatography assay

A validated liquid chromatography-mass spectrometry method was used to determine the plasmatic concentration of carvedilol [6].

The HPLC system was an Agilent 1100 series (binary pump, autosampler, thermostat) (Agilent Technologies ${ }^{\circledR}$, USA) and was coupled with a Bruker Ion Trap VL (Bruker Daltonics $\mathrm{GmbH}^{\circledR}$, Germany). A Zorbax SB-C18 chromatographic column $(50 \times 2.1 \mathrm{~mm}$, $3.5 \mu \mathrm{m}$ ) (Agilent Technologies ${ }^{\circledR}$, USA) was used. The mobile phase consisted of a 34:66 (v/v) mixture of acetonitrile and $0.2 \%(\mathrm{v} / \mathrm{v})$ formic acid in water. The flow rate was $0.5 \mathrm{~mL} / \mathrm{min}$, and the thermostat temperature was set at $42^{\circ} \mathrm{C}$. The mass spectrometry detection was in multiple reaction monitoring mode, positive ions, using an electrospray ionization source. The ion transitions monitored were $\mathrm{m} / \mathrm{z} 222,224$, 283 from $\mathrm{m} / \mathrm{z} 407$ for carvedilol. The calibration curve of carvedilol was linear at a concentration range of 6 - $577 \mathrm{ng} / \mathrm{mL}$ plasma.

\section{Pharmacokinetic Analysis}

The non-compartmental pharmacokinetic analysis using Phoenix WinNonlin software version 6.3 (Pharsight Co., Mountain View, CA, USA) was performed to determine the pharmacokinetic parameters of carvedilol given alone or in combination with fluvoxamine. The maximum plasma concentration $\left(\mathrm{C}_{\max }, \mathrm{ng} / \mathrm{mL}\right)$ and the time to reach the peak concentration $\left(\mathrm{T}_{\max }, \mathrm{hr}\right)$ were obtained directly by the visual inspection of each rat's plasma concentrationtime profile. The area under the concentration-time curve from time zero to the last measurable concentration at time $\mathrm{t}\left(\mathrm{AUC}_{0-\mathrm{t}}\right)$ was calculated using the trapezoidal rule. The area was extrapolated to infinity $\left(\mathrm{AUC}_{0-\infty}\right)$ by addition of $C_{t} / k_{e l}$ to $A_{U C} C_{0-t}$ where $C_{t}$ is the last quantifiable drug concentration and $\mathrm{k}_{\mathrm{el}}$ is the elimination rate constant. The elimination rate constant $\left(\mathrm{k}_{\mathrm{el}}\right)$ was calculated by log-linear regression of carvedilol 
concentration data during the elimination phase, and the terminal half-life $\left(\mathrm{t}_{1 / 2}\right)$ was calculated as $0.693 / \mathrm{k}_{\mathrm{el}}$. Experimental design

\section{Surgery}

One silicon rubber cannula $\left(\mathrm{BASi}^{\circledR}\right.$, Indiana, USA) (length, $18.5 \mathrm{~cm}$; internal diameter, $0.5 \mathrm{~mm}$; and external diameter, $0.94 \mathrm{~mm}$ ) was implanted in the left femoral vein. This procedural surgery was effectuated under the anesthesia with the same cocktail as above: diazepam, ketamine and xylazine $(1: 1: 1)$. The distal end of the cannula was tunnelled subcutaneously and exited between the ears. The venous cannula was used for blood sampling. The cannulation procedure was realized before connecting the rat to BASi Culex $\mathrm{ABC}^{\circledR}$.

\section{In vivo experimental design}

The study was open-label, sequential preclinical one and consisted of two periods: period 1 (reference), when each rat received carvedilol $3.57 \mathrm{mg} / \mathrm{kg}$ b.w. by oral route, and period 2 (test) when each rat received carvedilol $3.57 \mathrm{mg} / \mathrm{kg}$ b.w. and fluvoxamine 14.28 $\mathrm{mg} / \mathrm{kg}$ b.w. by oral route. Between the two periods, the rats were treated for 3 days with a single daily dose of fluvoxamine.

$200 \mu \mathrm{L}$ venous blood samples were drawn into heparinized tubes during both periods of the study at $5,10,15,20,30,45 \mathrm{~min}$ and 1, 2, 4, 8, 12, 18, 24, $30 \mathrm{~h}$ after carvedilol administration. The samples were stored frozen at $-20^{\circ} \mathrm{C}$ until analysis.

Statistical Analysis

The statistical analysis was performed using Phoenix WinNonlin software version 6.3 (Pharsight Co. ${ }^{\circledR}$, Mountain View, CA, USA) and were evaluated by one-way analysis of variance (ANOVA) for intergroup comparison. The level of significance was set at $\mathrm{p}<0.05$ for all analyses. All kinetic data were expressed as the mean \pm standard deviation (SD).

\section{Results and Discussion}

The carvedilol's mean plasma concentration-time profiles in presence or absence of fluvoxamine are illustrated in Figure 1.

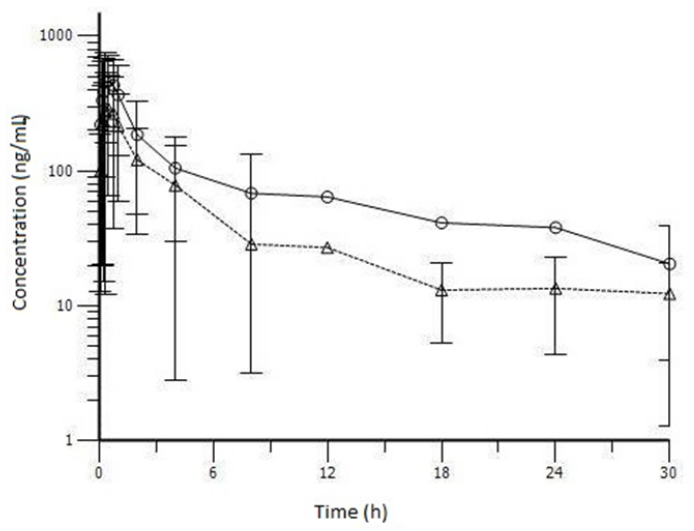

Figure 1.

Mean \pm SD plasma concentrations of carvedilol after the oral administration of carvedilol $(3.57 \mathrm{mg} / \mathrm{kg} \mathrm{b.w}$.) without $(\Delta)$ or with fluvoxamine $(14.28 \mathrm{mg} / \mathrm{kg}$ b.w.)

(o) in rats $(n=13)$.

The pharmacokinetic (PK) parameters and the statistical test results of carvedilol, when it was administered alone or with fluvoxamine, are summarized in Table I.

Main pharmacokinetic $(\mathrm{PK})$ parameters of carvedilol in rats $(\mathrm{n}=13)$ after single oral dose of $3.57 \mathrm{mg} / \mathrm{kg}$ b.w. of carvedilol, before and after treatment with fluvoxamine $(14.28 \mathrm{mg} / \mathrm{kg} \mathrm{b} . \mathrm{w}$.) for 3 days and the results of statistical test used for comparison

\begin{tabular}{|c|c|c|c|}
\hline $\begin{array}{c}\text { PK parameter } \\
(\text { mean } \pm \text { SD) }\end{array}$ & Carvedilol & $\begin{array}{l}\text { Carvedilol + } \\
\text { Fluvoxamine }\end{array}$ & $\begin{array}{l}p^{*} \text { value } \\
\text { (ANOVA) }\end{array}$ \\
\hline $\mathrm{C}_{\max }(\mathrm{ng} / \mathrm{mL})$ & $361.10 \pm 260.07$ & $528.50 \pm 288.20$ & $0.0651, \mathrm{NS}$ \\
\hline $\mathrm{t}_{\max }(\mathrm{hr})$ & $2.12 \pm 3.62$ & $0.95 \pm 1.31$ & $0.2722, \mathrm{NS}$ \\
\hline $\mathrm{AUC}_{0-\infty}(\mathrm{ng} * \mathrm{hr} / \mathrm{mL})$ & $1113.42 \pm 661.97$ & $2299.96 \pm 1465.32$ & $0.0059, \mathrm{~S}$ \\
\hline $\mathrm{k}_{\mathrm{el}}(1 / \mathrm{hr})$ & $0.30 \pm 0.42$ & $0.09 \pm 0.05$ & $0.0188, \mathrm{~S}$ \\
\hline $\mathrm{t}_{1 / 2}(\mathrm{hr})$ & $5.29 \pm 3.22$ & $12.42 \pm 12.69$ & $0.0188, \mathrm{~S}$ \\
\hline $\mathrm{Cl} \_\mathrm{F}(\mathrm{L} / \mathrm{hr} / \mathrm{kg})$ & $3677.29 \pm 2133.11$ & $2031.74 \pm 1389.79$ & $0.0174, \mathrm{~S}$ \\
\hline$\overline{\mathrm{Vz}} \mathrm{F}(\mathrm{L} / \mathrm{kg})$ & $25030.55 \pm 21297.51$ & $27486.02 \pm 19941.52$ & $0.5858, \mathrm{NS}$ \\
\hline
\end{tabular}

The $\mathrm{AUC}_{0-x}$ of carvedilol was significantly increased by $206.55 \%(p<0.05)$ in the presence of fluvoxamine after oral administration of carvedilol. Moreover, the body clearance and elimination half-life time were significantly affected by enzymatic inhibition of CYP2D6 and CYP1A2, the main enzymes responsible for the carvedilol's metabolism. The half-life time of carvedilol registered a 2.34 fold increase and the clearance $(\mathrm{Cl})$ registered a 0.55 fold decrease when it was co-administered with fluvoxamine.
There were no significant changes neither for the $\mathrm{C}_{\max }$ $(361.10 \pm 260.07$ vs $528.50 \pm 288.20)$ when coadministered with fluvoxamine nor $\mathrm{T}_{\max }(2.12 \pm 3.62$ vs $0.95 \pm 1.31)$. Although it was observed an increase with $46.35 \%$ for the value of $\mathrm{C}_{\max }$ and a decrease with $55.18 \%$ for the value of $\mathrm{T}_{\max }$, they were proved not be statistically significant.

There was reported a high prevalence of depression among patients with cardiovascular diseases [5]. Carvedilol improves the ejection fraction, symptomatic 
functional class, cardiac output and adrenergic activity. These advantages along with a potential increase in the risk for death with other $\beta_{1}$ selective blockers sustain the utilization of carvedilol in patients with cardiovascular diseases, especially for those with heart failure [8].

The most used drugs in the treatment of depression are selective serotonin reuptake inhibitors. Fluvoxamine is widely used for treatment of depression [26]. Because carvedilol is widely used to treat many cardiovascular diseases and is primarily metabolized by CYP2D6 and CYP1A2 [18] and fluvoxamine is a potent inhibitor of these metabolic pathway [17, 19], the clinical evaluation of this pharmacokinetic drugdrug interaction is important. The changes of CYP450 enzymes' function can generate drug-drug interactions. This interaction can have an impact on clinical practice for those patients who follow a concomitantly treatment with carvedilol and fluvoxamine. An elevated exposure over time to carvedilol was indicated by statistically significant alteration $(\mathrm{p}<0.05)$ of pharmacokinetic parameters $\left(\mathrm{AUC}_{0-\infty}, \mathrm{k}_{\mathrm{el}}, \mathrm{t}_{1 / 2}, \mathrm{Cl}\right)$ after fluvoxamine pre-treatment. The alteration of the pre-systemic metabolism appeared as a result of this drug-drug interaction. Fluvoxamine inhibits the main isoenzymes (CYP2D6, CYP1A2) which are involved in the metabolization of carvedilol at pre-systemic level.

Many pre-clinical and clinical previous studies demonstrated the pharmacokinetic drug-drug interaction between carvedilol and other CYP450 inhibitors, including citalopram [1], bupropion [2, 12], fluoxetine $[14,24]$, paroxetine [30], ketoconazole and voriconazole [33]. The results were similar with that obtained by fluvoxamine inhibition in the present study.

In the last years, the safety profiles of many drugs, especially cardiovascular medication, have been evaluated. Carvedilol is one of the most used beta blockers but its safety profile still need to be studied, especially from the drug-drug interaction point of view.

\section{Conclusions}

In conclusion, the present study demonstrated the pharmacokinetic drug-drug interaction between carvedilol and fluvoxamine in vivo, in rats.

Fluvoxamine significantly influenced the pharmacokinetic of carvedilol, due to its capacity of CYP2D6 and CYP1A2 inhibition. As a result of this interaction the exposure to carvedilol was significantly increased. This is the reason why co-administration of carvedilol and fluvoxamine needs precaution.

\section{Acknowledgement}

This work was supported by CNCS Romania - project PNII-RU-TE-2014-4-0242, project manager CS III Dr. Muntean Dana Maria.

\section{References}

1. Abrudan MB, Muntean DM, Popa DS, Gheldiu A-M, Neag MA, Vlase L, Inhibitory effect of citalopram on the pharmacokinetics of carvedilol in rats and in vitro models. Pharmacology, 2017; 100(5-6): 301-307.

2. Abrudan MB, Muntean DM, Gheldiu AM, Neag MA, Vlase L, The pharmacokinetic interaction study between carvedilol and bupropion in rats. Pharmacology, 2017; 99(3-4): 139-143.

3. Abrudan MB, Muntean DM, Neag MA, Vlase L, Gheldiu AM, The influence of sertraline on the pharmacokinetics of carvedilol. A preclinical study on rats. Farmacia, 2017; 65(4): 557-562.

4. Azuma J, Hasunuma T, Kubo M, Miyatake M, Koue T, Higashi K, Fujiwara T, Kitahara S, Katano T, Hara $\mathrm{S}$, The relationship between clinical pharmacokinetics of aripiprazole and CYP2D6 genetic polymorphism: Effects of CYP enzyme inhibition by coadministration of paroxetine or fluvoxamine. Eur J Clin Pharmacol., 2012; 68(1): 29-37.

5. Briciu C, Neag M, Muntean D, Vlase L, Bocșan C, Buzoianu A, Gheldiu AM, Achim M, Popa A, A pharmacokinetic drug interaction study between nebivolol and paroxetine in healthy volunteers. $J$ Clin Phar Ther., 2014; 39(5): 535-540.

6. Butnariu A, Popa DS, Vlase L, Andreica M, Muntean D, Leucuta S, New high-throughput liquid chromatographic tandem mass spectrometry assay for therapeutic drug monitoring of carvedilol in children with congestive heart failure. Rev Rom Med Lab., 2009; 15(2): 7-15.

7. Ciobanu AM, Pop AL, Crişan S, Pali M, BurceaDragomiroiu GTA, Popa DE, Lupuliasa D, Bârcă M, HPLC studies for assessing the stability of carvedilol tablets. Farmacia, 2017; 65(4): 523-531.

8. Dinicolantonio JJ, Lavie CJ, Fares H, Menezes AR, O'Keefe JH, Meta-analysis of carvedilol versus beta 1 selective beta-blockers (atenolol, bisoprolol, metoprolol, and nebivolol). Am J Cardiol., 2013; 111(5): 765-769.

9. Ghareghani M, Zibara K, Sadeghi H, Dokoohaki S, Sadeghi H, Aryanpour R, Ghanbari A, Fluvoxamine stimulates oligodendrogenesis of cultured neural stem cells and attenuates inflammation and demyelination in an animal model of multiple sclerosis. Sci Rep., 2017; 7(1): 1-17.

10. Gheldiu AM, Popa A, Neag M, Muntean D, Bocşan C, Buzoianu A, Vlase L, Achim M, Todor I, Briciu $\mathrm{C}$, Assessment of fluvoxamine effects on the pharmacokinetics of zolpidem and its metabolite in healthy volunteers. Farmacia, 2015; 63(3): 453-459.

11. Gheldiu AM, Vlase L, Popa A, Muntean D, Bocșan C, Buzoianu A, Neag M, Leucuța D, Briciu C, Assessment of the effects of steady-state bupropion on the pharmacokinetic profile of zolpidem in healthy volunteers. Farmacia, 2019; 67(3): 430-436.

12. Gheldiu AM, Popa A, Neag M, Muntean D, Bocşan C, Buzoianu A, Vlase L, Tomuță I, Briciu C, Assessment of a potential interaction between nebivolol and bupropion in healthy volunteers. Pharmacology, 2016; 98: 190-198.

13. Gheldiu AM, Vlase L, Popa A, Briciu C, Muntean D, Bocşan C, Buzoianu A, Achim M, Tomuță I, Todor 
FARMACIA, 2019, Vol. 67, 4

I, Leucuța D, Neag M, Investigation of a potential interaction between nebivolol and fluvoxamine in healthy volunteers. J Pharm Pharm Sci., 2017; 20: 68-80.

14. Graff DW, Williamson KM, Pieper JA, Carson SW, Adams KF, Cascio WE, Patterson JH, Effect of fluoxetine on carvedilol pharmacokinetics, CYP2D6 activity, and autonomic balance in heart failure patients. J Clin Pharmacol., 2001; 41(1): 97-106.

15. Henderson LS, Tenero DM, Baidoo CA, Campanile AM, Harter AH, Boyle D, Danoff TM, Pharmacokinetic and pharmacodynamic comparison of controlledrelease carvedilol and immediate-release carvedilol at steady state in patients with hypertension. $\mathrm{Am} \mathrm{J}$ Cardiol., 2006; 98(7A): 17-26.

16. Hiemke C, Härtter $\mathrm{S}$, Pharmacokinetics of selective serotonin reuptake inhibitors. Pharmacol Ther., 2000; 85(1): 11-28.

17. Hemeryck A, Belpaire FM, Selective serotonin reuptake inhibitors and cytochrome P-450 mediated drug-drug interactions: An update. Curr Drug Metab., 2002; 3(1): 13-37.

18. Iwaki $\mathrm{M}$, Niwa $\mathrm{T}$, Bandoh $\mathrm{S}$, Itoh $\mathrm{M}$, Hirose $\mathrm{H}$, Kawase A, Komura H, Application of substrate depletion assay to evaluation of CYP isoforms responsible for stereoselective metabolism of carvedilol. Drug Metab Pharmacokinet., 2016; 31(6): 425-432.

19. Jeppesen U, Gram LF, Vistisen K, Loft S, Poulsen HE, Brøsen K, Dose dependent inhibition of CYP1A2, CYP2C19 and CYP2D6 by citalopram, fluoxetine, fluvoxamine and paroxetine. Eur J Clin Pharmacol., 1996; 51(1): 73-78.

20. Katoh Y, Uchida S, Kawai M, Takei N, Mori N, Kawakami J, Hagawa Y, Yamada S, Namiki N, Hashimoto H, Onset of clinical effects and plasma concentration of fluvoxamine in Japanese patients. Biol Pharm Bull., 2010; 33(12): 1999-2002.

21. Keating GM, Jarvis B, Carvedilol: a review of its use in chronic heart failure. Drugs, 2003; 63(16): 1697-1741.

22. Lim TH, Cho YA, Choi DH, Effects of cilostazol on the pharmacokinetics of carvedilol after oral and intravenous administration in rats. $J$ Physiol Pharmacol., 2015; 66(4): 591-597.

23. Lymperopoulos A, McCrink K, Brill A, Impact of CYP2D6 genetic variation on the response of the cardiovascular patient to carvedilol and metoprolol. Curr Drug Metab., 2015; 17: 30-36.

24. Lynch T, Price A, The effect of cytochrome P450 metabolism on drug response, interactions, and adverse effects. Am Fam Physician., 2007; 76(3): 391-396.
25. Nardotto GHB, Lanchote VL, Coelho EB, Della Pasqua O, Population pharmacokinetics of carvedilol enantiomers and their metabolites in healthy subjects and type-2 diabetes patients. Eur $J$ Pharm Sci., 2017; 1-8.

26. Neag MA, Vlase L, Buzoianu AD, Bocşan CI, Mircea AP, Leucuța SE, Popa A, Muntean D, Pharmacokinetic interaction between fluvoxamine and lansoprazole in healthy volunteers. Int $J$ of the Bioflux Soc., 2010; 8(1): 59-64.

27. Nishioka K, Nakagawa K, Umemura T, Jitsuiki D, Ueda K, Goto C, Chayama K, Yoshizumi M, Higashi Y, Carvedilol improves endothelium-dependent vasodilation in patients with dilated cardiomyopathy. Heart, 2007; 93(2): 247-248.

28. Oldham HG, Clarke SE, In vitro identification of the human cytochrome P450 enzymes involved in the metabolism of R(+)- and S(-)-carvedilol. Drug Metab Dispos., 1997; 25(8): 970-977.

29. Stoschitzky K, Koshucharova G, Zweiker R, Maier $\mathrm{R}$, Watzinger N, Fruhwald FM, Klein W, Differing beta-blocking effects of carvedilol and metoprolol. Eur J Heart Fail., 2001; 3(3): 343-349.

30. Stout SM, Nielsen J, Bleske BE, Shea M, Brook R, Kerber K, Welage LS, The Impact of paroxetine coadministration on stereospecific carvedilol pharmacokinetics. J Cardiovasc Pharmacol Ther., 2010; 15(4): 373-379.

31. Tian X, Zhao C, Guo J, Xie S, Yin F, Huo X, Zhang $\mathrm{X}$, Carvedilol attenuates the progression of hepatic fibrosis induced by bile duct ligation. Biomed Res Int., 2017; 2017:1-10.

32. Todor I, Popa A, Neag M, Muntean D, Bocsan C, Buzoianu A, Vlase L, Gheldiu AM, Briciu C, Evaluation of the potential pharmacokinetic interaction between atomoxetine and fluvoxamine in healthy volunteers. Pharmacology, 2017; 99(1-2): 84-88.

33. Wang L, Wang S, Chen M, Chen X, Lin Y, Hu X, Huang $X$, Li X, Inhibitory effect of ketoconazole and voriconazole on the pharmacokinetics of carvedilol in rats. Drug Dev Ind Pharm, 2015; 41(10): 1661-1666.

34. Zhang J, Zhou Q, Smith CD, Chen H, Tan Z, Chen B, Nani A, Wu G, Song LS, Fill M, Back TG, Non- $\beta$ blocking R-carvedilol enantiomer suppresses $\mathrm{Ca}^{2+}$ waves and stress-induced ventricular tachyarrhythmia without lowering heart rate or blood pressure. Biochem J., 2015; 470(2): 233-242.

35. Zisaki A, Miskovic L, Hatzimanikatis V, Antihypertensive drugs metabolism: An update to pharmacokinetic profiles and computational approaches. Curr Pharm Des., 2015; 21(6): 806-822. 